\title{
Influence of different protein supplements on the recovery and in vitro maturation of bovine oocytes
}

\author{
Influencia de diferentes suplementos proteicos en la recuperación y maduración in vitro de ovocitos \\ bovinos
}

\section{Influência de diferentes suplementações proteicas sobre a recuperação e maturação in vitro de oócitos bovinos}

Pedro H Fernandes-França D; Maria V Oliveira-Santos 1 ; Gabriela P Oliveira-Lira ${ }^{D}$; Alana Azevedo-Borges ${ }^{D}$;

Alexsandra Fernandes-Pereira* iD.

\begin{abstract}
Laboratório de Biotecnologia Animal, Departamento de Biociências, Centro de Ciências Biológicas e da Saúde, Universidade Federal Rural do Semi-Árido, Mossoró, Rio Grande do Norte, Brasil.
\end{abstract}

To cite this article:

Fernandes-França PH, Oliveira-Santos MV, Oliveira-Lira GP, Azevedo-Borges A, Fernandes-Pereira A. Influence of different protein supplements on the recovery and in vitro maturation of bovine oocytes. Rev Colomb Cienc Pecu 2020; 33(3): $172-181$. DOI: https://doi.org/10.17533/udea.rccp.v33n3a01

\begin{abstract}
Background: Oocyte quality and maturation are influenced by protein supplementation. Objective: To evaluate the influence of fetal bovine serum (FBS) and bovine serum albumin (BSA) concentrations on the recovery and in vitro maturation (IVM) of bovine oocytes. Methods: The study was divided into Stage 1 (oocyte recovery), and Stage 2 (IVM). In the first stage, three experiments were conducted according to the recovery (R) medium used: (R1) $10 v s .20 \%$ FBS; (R2) 5 vs. 10\% BSA; and (R3) the best results from R1, R2, and the combination of FBS+BSA (5+5\%). Within the second stage, the maturation medium was supplemented according to three experiments: (M1) 5 vs. 10\% FBS; (M2) 0.4 vs. 0.8\% BSA; and (M3) better results of M1, M2, and the combination of FBS+BSA (5+0.8\%). Results: In Stage 1 (R1 and R2), the media with $10 \%$ FBS and $10 \%$ BSA showed better oocyte quality results and were defined for experiment R3. In R3, the $10 \%$ FBS and the combination of FBS+BSA $(5+5 \%)$ allowed recovery of better-quality oocytes. In Stage 2 (M1 and M2), media with both levels of FBS (5 and $10 \%$ ) and $0.8 \%$ BSA were defined as better according to the maturation and viability rates of cumulus cells, so they were defined for experiment M3. In M3, no difference was noted among the supplements. Conclusions: For oocyte recovery, 10\% FBS and the combination of FBS+BSA $(5+5 \%)$ can be used to obtain immature oocytes. For the in vitro maturation, FBS (both levels, 5 and $10 \%)$ and BSA $(0.8 \%)$ can be used alone or in combination.
\end{abstract}

Keywords: bovine serum albumin; brilliant cresyl blue; fetal bovine serum; in vitro embryo production; meiotic competence; oocyte maturation; oocyte quality; oocyte recovery.

Received: May 2, 2018; accepted: November 4, 2019

*Corresponding autor. Av. Francisco Mota, 572, Costa e Silva, 59625-900, Mossoró, Brasil. Tel.: +55 85999036715.

E-mail: alexsandra.pereira@ufersa.edu.br 


\section{Resumen}

Antecedentes: La calidad y maduración de los ovocitos son influenciados por la suplementación proteica. Objetivo: Evaluar la influencia de concentraciones de suero fetal bovino (FBS) y albúmina sérica bovina (BSA) en la recuperación y maduración in vitro (IVM) de ovocitos bovinos. Métodos: El estudio se dividió en Etapa 1 (recuperación de ovocitos) y Etapa 2 (IVM). En la primera etapa, tres experimentos se realizaron de acuerdo con el medio de recuperación: (R1) 10 vs. $20 \%$ FBS; (R2) 5 vs. 10\% BSA; y (R3) los mejores resultados de R1, R2 y la combinación de FBS+BSA (5+5\%). En la segunda etapa, el medio de maduración fue suplementado para tres experimentos: (M1) 5 vs. 10\% FBS; (M2) 0,4 vs. 0,8\% BSA; y (M3) mejores resultados de M1, M2 y la combinación de FBS+BSA (5+0,8\%). Resultados: En la Etapa 1 (R1 y R2), los medios con $10 \%$ FBS y $10 \%$ BSA mostraron mejores resultados de calidad oocitaria y fueron definidos para el experimento R3. En R3, 10\% FBS y la combinación de FBS+BSA (5+5\%) permitieron la recuperación de ovocitos de mejor calidad. En la Etapa 2 (M1 y M2), los medios con ambos niveles de FBS (5 y 10\%) y 0,8\% de BSA se definieron como mejores de acuerdo con las tasas de maduración y viabilidad de las células del cumulus, por lo que se definieron para el experimento M3. En M3, no se observó diferencia entre los suplementos. Conclusiones: Para la recuperación de ovocitos, se puede utilizar 10\% de FBS y la combinación de FBS+BSA (5+5\%) para obtener ovocitos inmaduros. Para la maduración in vitro, FBS (ambos niveles, 5 y $10 \%)$ y BSA $(0,8 \%)$ se pueden usar solos o en combinación.

Palabras clave: albúmina sérica bovina; azul de cresil brillante; calidad de los ovocitos; competencia meiótica; maduración de ovocitos; producción de embriones in vitro; recuperación de ovocitos; suero fetal bovino.

\section{Resumo}

Antecedentes: A qualidade e a maturação de oócitos são influenciadas pela suplementação proteica. Objetivo: Avaliar a influência de concentrações de soro fetal bovino (FBS) e albumina sérica bovina (BSA) sobre a recuperação e maturação in vitro (IVM) de oócitos bovinos. Métodos: O estudo foi dividido em Etapa 1 (recuperação de oócitos) e Etapa 2 (IVM). Na primeira etapa, três experimentos foram realizados de acordo com o meio de recuperação: (R1) 10 vs. 20\% FBS; (R2) 5 vs. 10\% BSA; e (R3) melhores resultados de R1, R2 e a combinação de FBS+BSA (5+5\%). Na segunda etapa, o meio de maturação foi suplementado de acordo com três experimentos: (M1) 5 vs. 10\% FBS; (M2) 0,4 vs. 0,8\% BSA; e (M3) melhores resultados de M1, M2 e a combinação de FBS+BSA (5+0,8\%). Resultados: Na Etapa 1 (R1 e R2), os meios com 10\% FBS e 10\% BSA mostraram melhores resultados de qualidade oocitária e foram definidos para o experimento R3. Em R3, 10\% FBS e a combinação de FBS+BSA (5+5\%) permitiram a recuperação de oócitos de melhor qualidade. Na segunda etapa (M1 e M2), meios com ambos os níveis de FBS (5 e 10\%) e 0,8\% BSA foram definidos como os melhores de acordo com as taxas de maturação e viabilidade de células do cumulus, então foram definidos para o experimento M3. No M3, não houve diferença entre os suplementos. Conclusões: Para a recuperação oocitária, $10 \%$ FBS e a combinação de FBS+BSA $(5+5 \%)$ podem ser usados para obter oócitos imaturos. Para maturação in vitro, FBS (ambos os níveis, 5 e 10\%) e BSA (0,8\%) podem ser usados sozinhos ou em combinação.

Palavras-chave: albumina sérica bovina; azul cresil brilhante; competência meiótica; maturação oocitária; produção in vitro de embriões; qualidade do oócito; recuperação do oocitária; soro fetal bovino. 


\section{Introduction}

In vitro embryo production (IVEP) has been prominent over the years, especially for domestic animals, such as cattle (Boruszewska et al., 2016). Nevertheless, IVEP its efficiency is limited; it can generate about $30-50 \%$ of viable blastocysts (Gonçalves et al., 2007; Pereira et al., 2010). Thus, improvements are required in the culture conditions of various stages of IVEP, such as oocyte recovery, in vitro maturation (IVM) of selected oocytes, and fertilization (IVF) and development (IVD) of presumed zygotes to blastocyst stage to be transferred or cryopreserved (Varago et al., 2008).

These initial stages of oocyte recovery and maturation are of great importance for better results, as the quality of cumulus-oocyte complexes (COCs) obtained determines the later stages of the technique (Santos et al., 2016; Santos et al., 2017). Therefore, to ensure nutrition and energy support during in vitro oocyte development, the media requires supplementation with external protein sources. Commonly used protein sources are fetal bovine serum (FBS) and bovine serum albumin (BSA) (Ambrogi et al., 2017).

FBS is an undefined source of protein, consisting of a combination of proteins, growth factors, hormones, vitamins, and other nutrients present in the blood plasma (Van Der Valk et al., 2010; Leivas et al., 2011). In contrast, BSA is a purified protein present at high concentrations in blood plasma, with high capacity and affinity for binding with other biomolecules (Muñoz and Mischler, 2015). Despite extensive use, the concentration of FBS and BSA in the recovery and maturation media varies among protocols, whether used alone or in combination (Sugimura et al., 2018). Therefore, establishing the ideal concentration according to the influence on oocyte quality and maturation rate can contribute to increasing the success of IVEP.

Thus, the present study aimed to evaluate the quality of immature bovine oocytes recovered and selected in medium containing different concentrations of FBS (10vs. 20\%) and BSA ( 5 vs. $10 \%$ ), as well as to analyze the effect of these protein sources on the IVM of bovine oocytes (FBS: 5 vs. 10\%; BSA: 0.4 vs. 0.8\%).

\section{Materials and Methods}

\section{Ethical considerations}

The study was conducted according to the Institutional Committee on Animal Use at Universidade Federal Rural do Semi-Árido, Mossoró, Rio Grande do Norte, Brasil. (CEUA/ UFERSA, no. 23091.001069/2015-79). All reagents used were from Sigma-Aldrich ${ }^{\circledR}$ (Sigma, St Louis, MO, USA), except where indicated.

\section{Study design}

The study was divided into two stages. In Stage 1, protein sources were added in the recovery medium and in Stage 2 in the IVM medium. In the first stage, oocytes were obtained in recovery medium containing phosphate buffered saline (PBS) solution, and three experiments were performed according to the following supplements: (R1) $10 v s$. 20\% FBS (Gibco, Carlsbad, Kentucky, EUA); (R2) 5 vs. 10\% BSA; and (R3) was the best combination that resulted from experiments $\mathrm{R} 1$, $\mathrm{R} 2$, and the combination of FBS+BSA $(5+5 \%)$. Thus, the best results were defined according to the highest recovery rate, proportion of viable oocytes based on morphology, and proportion of viable oocytes based on brilliant cresyl blue $(\mathrm{BCB})$ in each experiment. Additionally, a high percentage of viable oocytes were considered more significant during the evaluation of the results. After recovery, oocytes were evaluated for morphological appearance and BCB assay. In the second stage, we aimed to evaluate protein sources in the IVM medium; three experiments were conducted to compare the following: (M1) 5 vs. $10 \%$ FBS; (M2) 0.4 vs. $0.8 \%$ BSA; and (M3) best results from experiments M1, M2 and the combination of FBS+BSA $(5+0.8 \%)$. Thus, the best results were defined according to better rates of expansion and viability of 
cumulus cells (CCs), presence of the first polar body (1PB) and metaphase plate (MII) for each experiment. For this purpose, oocytes were recovered in TCM199 supplemented with 10\% FBS, $40 \mu \mathrm{g} / \mathrm{mL}$ gentamicin sulfate, and $0.2 \mathrm{mM}$ sodium pyruvate. They were subjected to IVM and evaluated for the expansion and viability of $\mathrm{CCs}$, the presence of the 1PB, and MII.

\section{Ovarian collection and oocyte recovery}

Bovine ovaries $(n=735)$ were collected at a local slaughterhouse (Mossoró, Rio Grande do Norte, Brazil). Immediately after slaughter, the ovaries were transported in saline solution $(\mathrm{NaCl}, 0.9 \%)$ at $35{ }^{\circ} \mathrm{C}$ for up to $30 \mathrm{~min}$. Once in the laboratory, follicular aspiration was performed with the aid of $21 \mathrm{G}$ needles coupled to $5 \mathrm{~mL}$ syringes for $10-20$ min. Thus, only visible follicles on the ovarian surface, with a diameter of 2-8 mm, were counted and aspirated. The follicular fluid obtained was kept at rest for 15 min for sedimentation of the oocytes. The time between ovarian collection and oocyte recovery was approximately $60 \mathrm{~min}$.

\section{Morphological evaluation and bright cresyl blue assay}

The recovered COCs were morphologically classified as either viable (one or more layers of CCs and homogeneous cytoplasm) or non-viable (less than one layer of CCs and heterogeneous or degenerated cytoplasm), according to Santos et al. (2016).

For the BCB assay, oocytes selected by morphological criteria were washed in PBS and incubated in drops of BCB diluted in PBS $(26 \mu \mathrm{M})$ for $60 \mathrm{~min}$ at $38.5^{\circ} \mathrm{C}$. Then, under stereomicroscope (Bel Photonics, Monza, BM, Italy), oocytes with blue staining in their cytoplasm were considered $\mathrm{BCB}^{+}$and more competent. Those with unchanged cytoplasm were considered BCB- and less competent. This test is based on the ability of the enzyme glucose-6-phosphate dehydrogenase (G6PDH) to reduce BCB from blue to colorless in growing oocytes, whereas in oocytes grown at low activity the enzyme allows them to remain blue (Maia et al., 2017).
In vitro maturation (IVM) and evaluation of mature oocytes

In Stage 2, after oocyte retrieval, 20-30 morphologically classified as viable oocytes were transferred to droplets (covered with mineral oil) of the IVM medium consisting of TCM199 supplemented with $100 \mu \mathrm{M}$ cysteamine, $0.2 \mathrm{mM}$ sodiumm pyruvate, 40 $\mu \mathrm{g} / \mathrm{mL}$ gentamicin sulfate, $10 \mu \mathrm{g} / \mathrm{mL}$ FSH/LH (Pluset ${ }^{\circ}$, Callier, Buenos Aires, ARG), and a protein source. The IVM was performed in petri dishes (Corning, Corning, NY, USA) at $38.5^{\circ} \mathrm{C}$ in a humid atmosphere with $5 \% \mathrm{CO} 2$ for $24 \mathrm{~h}$.

After IVM, oocytes with expanded CCs, identified under stereomicroscope, were considered mature and those that did not show expansion were considered immature. To evaluate viability of CCs, the oocytes were denuded by repeated pipetting and the resulting cell suspension was stained with trypan blue $(0.2 \%)$. The cells were counted in the four quadrants at the edges of a Neubauer chamber, where blue and non-stained cells were considered dead and live, respectively.

After CC removal, the oocytes were morphologically evaluated for the presence of $1 \mathrm{~PB}$ under stereomicroscope. Structures showing the 1PB were considered mature. Furthermore, the nuclear stage of the oocytes was evaluated by fluorescence microscopy. For this, oocytes were fixed in paraformaldehyde (4\%) and stained with Hoechst 33342 (10 $\mu \mathrm{g} /$ $\mathrm{mL}$ ) for $15 \mathrm{~min}$. Only oocytes with nuclear stage in metaphase II were classified as mature.

\section{Statistical analysis}

Recovery rates (oocytes recovered of the total of aspirated follicles), oocyte quality (viable oocytes of the total oocytes recovered), and maturation rates (oocytes showing expanded CCs, presence of $1 \mathrm{~PB}$, and MII of total oocytes evaluated) were compared among the groups and the results were analyzed by the Fisher's exact test (GraphPad Software INSTAT 3.06). The viability rate of CCs (live cells/total cells counted $\times 100$ ) was analyzed by the Chi-square 
test. Data were expressed as mean \pm standard error and considered different when $p<0.05$. In each experiment, five replicates were used.

\section{Results}

Stage 1 (Table 1) consisted of the evaluation of protein supplementation in immature bovine oocyte collection media. A total of 266 ovaries lead to 1.978 oocytes, with a mean of 7.4 oocytes retrieved per ovary. Thus, in experiment R1, $10 \%$ FBS was superior $(p<0.05)$ to the $20 \%$ FBS group for morphological evaluation, and lower in the BCB test. Nevertheless, despite the superior result in the BCB test for $20 \%$ FBS, this occurred due to a higher amount of morphologically non-viable oocytes. In experiment R2, $10 \%$ BSA presented better morphological results compared to $5 \%$ BSA $(\mathrm{p}<0.05)$. Nevertheless, the two BSA concentrations showed statistically similar results in the BCB assay. Thus, $10 \%$ FBS and $10 \%$ BSA were used in R3.

In the latter experiment, 10\% FBS and $10 \%$ BSA were compared to $5+5 \% \mathrm{FBS}+\mathrm{BSA}$ combination. The $10 \%$ BSA group had higher recovery rate than the other groups. However, the combination of protein sources obtained higher number of morphologically viable oocytes. In contrast, $10 \%$ FBS medium showed higher percentage of viable oocytes using the BCB assay. Therefore, supplements that achieved positive results for oocyte quality, that is, $\mathrm{FBS}+\mathrm{BSA}(5+5 \%)$ combination and $10 \%$ FBS, were considered better.

Table 1. Evaluation of several concentrations of protein supplements in bovine immature oocyte recovery medium (R): Recovery 1 (10 vs. 20\% FBS), R2 (5 vs. 10\% BSA), and R3 (combination of FBS+BSA (5+5\%) vs. $10 \%$ FBS vs. $10 \%$ BSA).

\begin{tabular}{cccccccc}
\hline & \multicolumn{3}{c}{ Recovery 1 (R1) } & \multicolumn{2}{c}{ Recovery 2 (R2) } & \multicolumn{2}{c}{ Recovery 3 (R3) } \\
\cline { 2 - 8 } Parameters & $\mathbf{1 0 \%}$ FBS & $\mathbf{2 0 \%}$ FBS & $\mathbf{5 \% ~ B S A ~}$ & $\mathbf{1 0 \%}$ BSA & $\begin{array}{c}\text { FBS+BSA } \\
\mathbf{( 5 + 5 \% )}\end{array}$ & $\mathbf{1 0 \%}$ FBS & $\mathbf{1 0 \% ~ B S A ~}$ \\
\hline Recovery rate, \% (n) & $56.2 \pm 6.9^{\mathrm{a}}$ & $63.0 \pm 5.9^{\mathrm{a}}$ & $53.5 \pm 5.0^{\mathrm{a}}$ & $45.3 \pm 6.4^{\mathrm{b}}$ & $40.9 \pm 4.8^{\mathrm{b}}$ & $41.9 \pm 3.1^{\mathrm{b}}$ & $53.0 \pm 5.5^{\mathrm{a}}$ \\
& $(168 / 299)$ & $(216 / 343)$ & $(283 / 529)$ & $(203 / 448)$ & $(201 / 491)$ & $(239 / 570)$ & $(219 / 413)$ \\
Viable oocytes by & $75.6 \pm 4.9^{\mathrm{a}}$ & $58.8 \pm 6.9^{\mathrm{b}}$ & $64.3 \pm 8.4^{\mathrm{b}}$ & $73.9 \pm 3.6^{\mathrm{a}}$ & $79.6 \pm 2.0^{\mathrm{a}}$ & $68.6 \pm 4.8^{\mathrm{b}}$ & $63.6 \pm 4.5^{\mathrm{b}}$ \\
morphology, \% (n) & & & & & & & \\
& $(127 / 168)$ & $(127 / 216)$ & $(182 / 283)$ & $(150 / 203)$ & $(160 / 201)$ & $(164 / 239)$ & $(148 / 219)$ \\
Viable oocytes by & $38.7 \pm 8.9^{\mathrm{a}}$ & $49.5 \pm 8.3^{\mathrm{b}}$ & $11.0 \pm 3.8^{\mathrm{a}}$ & $17.2 \pm 1.8^{\mathrm{a}}$ & $18.4 \pm 3.7^{\mathrm{b}}$ & $29.3 \pm 5.5^{\mathrm{a}}$ & $11.4 \pm 3.9^{\mathrm{b}}$ \\
BCB, \% (n) & $(65 / 168)$ & $(107 / 216)$ & $(31 / 283)$ & $(35 / 203)$ & $(37 / 201)$ & $(70 / 239)$ & $(25 / 219)$ \\
\hline
\end{tabular}

Values are means $(\%) \pm$ Standard Error (n). Different superscript letters $\left({ }^{a}, b\right)$ in each experiment (R1, R2 and R3) within the same row indicate significant difference $(\mathrm{p}<0.05)$.

Stage 2 (Table 2) aimed to evaluate these supplements in the IVM media. A total of 469 ovaries resulted in 1.040 morphologically viable oocytes (2.2 viable oocytes per ovary). As for experiment $\mathrm{M} 1$, there was no difference ( $>0.05$ ) between 5 and 10\% FBS groups regarding expansion and viability of $\mathrm{CCs}$, presence of $1 \mathrm{~PB}$ and MII.
Therefore, 5 and 10\% FBS were evaluated in the M3 experiment.

In experiment $\mathrm{M} 2,0.8 \%$ BSA was superior $(p<0.05)$ only for viability of CCs compared to $0.4 \%$ BSA. $0.8 \%$ BSA was used in the subsequent experiments. In experiment M3, 5, $10 \% \mathrm{FBS}, 0.8 \% \mathrm{BSA}$ and the FBS+BSA $(5+0.8 \%)$ combination were similar $(p>0.05)$ for all parameters. 
Table 2. Evaluation of several concentrations of protein supplements for in vitro maturation medium (IVM) of bovine oocytes: Maturation 1 (5 vs. 10\% FBS), M2 (0.4 vs. 0.8\% BSA), and M3 (combination of FBS+BSA $(5+0.8 \%) v s .5 \%$ FBS $v s .10 \%$ FBS $v s .0 .8 \%$ BSA).

\begin{tabular}{|c|c|c|c|c|c|c|c|c|}
\hline \multirow[b]{2}{*}{ Parameters } & \multicolumn{2}{|c|}{ Maturation 1 (M1) } & \multicolumn{2}{|c|}{ Maturation 2 (M2) } & \multicolumn{4}{|c|}{ Maturation 3 (M3) } \\
\hline & $5 \%$ FBS & $10 \%$ FBS & $0.4 \%$ & $0.8 \%$ BSA & $\begin{array}{c}\text { FBS+BSA } \\
(5+0.8 \%)\end{array}$ & $5 \%$ FBS & $10 \%$ FBS & $0.8 \%$ BSA \\
\hline & \multicolumn{8}{|c|}{ Cumulus cells } \\
\hline $\begin{array}{l}\text { Expansion, } \\
\%(\mathrm{n})\end{array}$ & $\begin{array}{c}100.0 \pm 0.0^{\mathrm{a}} \\
(84 / 84)\end{array}$ & $\begin{array}{c}97.8 \pm 2.7^{\mathrm{a}} \\
(92 / 94)\end{array}$ & $\begin{array}{c}100.0 \pm 0.0^{\mathrm{a}} \\
(116 / 116)\end{array}$ & $\begin{array}{c}97.8 \pm 0.0^{\mathrm{a}} \\
(113 / 113)\end{array}$ & $\begin{array}{c}98.1 \pm 1.5^{\mathrm{a}} \\
(103 / 105)\end{array}$ & $\begin{array}{c}99.0 \pm 1.4^{\mathrm{a}} \\
(104 / 105)\end{array}$ & $\begin{array}{c}97.6 \pm 1.4^{\mathrm{a}} \\
(109 / 110)\end{array}$ & $\begin{array}{c}93.3 \pm 2.3^{\mathrm{a}} \\
(98 / 105)\end{array}$ \\
\hline \multirow[t]{2}{*}{$\begin{array}{l}\text { Viability, } \\
\%(n)\end{array}$} & $\begin{array}{c}73.0 \pm 13.9^{\mathrm{a}} \\
(842 / 1154)\end{array}$ & $\begin{array}{l}71.0 \pm 9.7^{\mathrm{a}} \\
(719 / 1012)\end{array}$ & $\begin{array}{c}56.0 \pm 4.2^{b} \\
(1740 / 3109)\end{array}$ & $\begin{array}{l}59.2 \pm 14.3^{\mathrm{a}} \\
(1458 / 2464)\end{array}$ & $\begin{array}{c}56.1 \pm 4.0^{\mathrm{a}} \\
(1325 / 2361)\end{array}$ & $\begin{array}{c}56.9 \pm 3.3^{\mathrm{a}} \\
(1151 / 2024)\end{array}$ & $\begin{array}{c}57.6 \pm 2.2^{\mathrm{a}} \\
(1352 / 2348)\end{array}$ & $\begin{array}{c}58.5 \pm 3.6^{\mathrm{a}} \\
(1149 / 1965)\end{array}$ \\
\hline & \multicolumn{8}{|c|}{ Nuclear stage } \\
\hline $\begin{array}{l}1 \mathrm{~PB}, \\
\%(\mathrm{n})\end{array}$ & $\begin{array}{c}84.1 \pm 6.0^{\mathrm{a}} \\
(69 / 84)\end{array}$ & $\begin{array}{c}78.3 \pm 4.0^{\mathrm{a}} \\
(72 / 92)\end{array}$ & $\begin{array}{c}80.2 \pm 9.5^{\mathrm{a}} \\
(93 / 116)\end{array}$ & $\begin{array}{c}87.6 \pm 4.9^{\mathrm{a}} \\
(99 / 113)\end{array}$ & $\begin{array}{c}89.7 \pm 5.4^{\mathrm{a}} \\
(78 / 87)\end{array}$ & $\begin{array}{c}88.7 \pm 5.2^{\mathrm{a}} \\
(86 / 97)\end{array}$ & $\begin{array}{c}79.5 \pm 6.4^{\mathrm{a}} \\
(83 / 98)\end{array}$ & $\begin{array}{c}87.5 \pm 3.0^{\mathrm{a}} \\
(91 / 104)\end{array}$ \\
\hline $\begin{array}{l}\text { MII, } \\
\%(n)\end{array}$ & $\begin{array}{c}60.3 \pm 3.9^{\mathrm{a}} \\
(41 / 68)\end{array}$ & $\begin{array}{c}54.0 \pm 6.6^{\mathrm{a}} \\
(47 / 87)\end{array}$ & $\begin{array}{c}69.7 \pm 13.1^{\mathrm{a}} \\
(76 / 109)\end{array}$ & $\begin{array}{c}60.2 \pm 1.8^{\mathrm{a}} \\
(56 / 93)\end{array}$ & $\begin{array}{c}62.7 \pm 11.3^{\mathrm{a}} \\
(42 / 67)\end{array}$ & $\begin{array}{c}60.8 \pm 4.3^{\mathrm{a}} \\
(48 / 79)\end{array}$ & $\begin{array}{c}65.8 \pm 9.9^{\mathrm{a}} \\
(52 / 79)\end{array}$ & $\begin{array}{c}66.7 \pm 4.5^{\mathrm{a}} \\
(48 / 72)\end{array}$ \\
\hline
\end{tabular}

Values are means $(\%) \pm$ Standard Error (n). Different superscript letters $\left({ }^{a}, b\right)$ in each experiment (M1, M2 and M3) within the same row indicate significant difference $(\mathrm{p}<0.05)$. 1PB: first polar body. MII: metaphase II.

\section{Discussion}

Several concentrations of two protein sources (FBS and BSA) were evaluated for bovine oocyte recovery and IVM media. In the recovery medium (R1), 10\% FBS presented the best result for morphological quality in comparison with $20 \%$ FBS. This demonstrates that even at low concentration FBS is able to provide good nutrition to the oocytes during the recovery while maintaining high quality for IVM. In contrast, a better effect of BSA (R2) was observed at the highest concentration tested $(10 \%)$, probably due to the simpler composition of this supplement. Nevertheless, in the third experiment (R3), when comparing 10\% FBS, $10 \% \mathrm{BSA}$, and FBS+BSA $(5+5 \%)$ combination, the most favorable supplement mix for oocyte quality were $10 \% \mathrm{FBS}$ and $\mathrm{FBS}+\mathrm{BSA}(5+5 \%)$ combination.

In general, FBS concentration in the oocyte recovery media is variable. Chasombat et al. (2015) used 10\% FBS in bovine oocyte retrieval medium obtaining good blastocyst rate $(30.9 \%)$ at the end of IVF. On the other hand, Chen et al. (2016) used a 2\% FBS during the recovery and reached $23.0 \%$ blastocysts after 8 days of culture of the embryos generated. Furthermore, with respect to BSA, previous studies show variations in the quantities used. As an example, Ulloa et al. (2014) compared bovine oocyte harvesting methods using $0.1 \%$ BSA and obtained 79.8\% maturation after follicular aspiration. In the study by Carrocera et al. (2016), bovine oocyte recovery medium was supplemented with $0.4 \%$ BSA and, after IVF, up to $37.5 \%$ blastocyst was obtained. In other species, such as pigs and mice, the use of $0.4 \%$ (Galeati et al., 2010) and 10\% (Dinopoulou et al., 2016) BSA has also been reported. The conjugation of FBS+BSA $(5+5 \%)$ in the recovery medium may be an interesting supplement since it allowed a great nutritional contribution to the oocytes and showed a better rate of $\mathrm{BCB}^{+}$oocytes.

The use of the BCB assay for the selection of viable bovine oocytes proved to be an efficient method by allowing the semi-quantification of G6PDH enzyme, indicative of the stage of oocyte development. According to Ashry et al. (2015), oocytes classified as $\mathrm{BCB}^{+}$in the recovery stage are more competent for embryonic development. From this, it is suggested to perform this 
technique in conjunction with morphological evaluation since morphologically non-viable oocytes for IVEP can also be stained with the dye.

In the IVM stage, different concentrations of FBS and BSA were evaluated separately and associated; then, the best results were compared with a group containing both supplements. Regarding FBS, both tested concentrations (5 and 10\%) showed no difference. In the experiment with BSA (M2), $0.8 \%$ was superior compared to $0.4 \%$ regarding $\mathrm{CCs}$ viability. Previously, Ali and Sirard (2002) compared different protein sources during maturation. They verified the effect of free fatty acid BSA $(0.8 \%)$, isolated BSA $(0.8 \%)$, chicken egg albumin, polyvinylpyrrolidone (PVP) $(0.8 \%)$, and $10 \%$ FBS in the media, and obtained low maturation rate $(44.0 \%)$ when using $0.8 \%$ BSA, but achieved the best results using PVP supplementation, which is different from the results of the present study.

The cells surrounding the oocyte are of great importance for oocyte maturation, as they have gonadotrophin receptors (FSH and $\mathrm{LH})$, communicate, and exchange nutrients and molecules important for oocyte development (Crocomo et al., 2011). Thus, the evaluation of CCs is important for efficient IVM, because the viability parameter reveals the normal functioning of oocyte communication and media efficiency, and the expansion is related to cytoplasmic maturation (Araújo et al., 2014).

In the M3 experiment, concentrations of 5 and $10 \% \mathrm{FBS}, 0.8 \% \mathrm{BSA}$, and the FBS+BSA $(5+0.8 \%)$ combination were compared. According to Del Collado et al. (2014), low FBS concentrations in IVMcan generate results similar to those obtained under high FBS concentrations. Thus, the lowest FBS concentration (5\%) was used in the medium containing the conjugation of the protein sources. After evaluating CCs and nuclear stage, all groups presented similar results. This could be because the FBS and BSA concentrations have enough nutrients to ensure oocyte development. Furthermore, Ambrogi et al. (2017) compared the transport of bovine oocytes in media supplemented with $10 \%$ FBS or $0.6 \%$ BSA followed by IVM with 10\% FBS and found no differences in MII rates, blastocysts, cryotolerance, levels of reactive oxygen species, and mitochondrial distribution (cytoplasmic maturation). This shows that the two supplements have similar efficiency.

The use of more than one protein source during the same stage of IVEP has been reported by other researchers. Leivas et al. (2011) used a medium supplemented with BSA and FBS to culture bovine embryos and obtained up to $43 \%$ blastocyst rates. Del Collado et al. (2015) compared FBS+BSA $(5+0.6 \%)$ conjugation during IVM where $89.6 \%$ maturation was reached in the presence of $1 \mathrm{~PB}$, a result very similar to that obtained in the present study $(89.7 \%)$. These authors suggest that the presence of only BSA in the IVM medium is less effective compared to a medium containing both protein sources. Therefore, it is believed that supplementation of FBS together with BSA presents greater protein supply for COCs development, by combining positive characteristics of both supplements. However, when used alone at suitable concentrations, FBS and BSA show positive and similar results and can be used for bovine oocyte IVM.

In conclusion, supplementation with FBS + BSA $(5+5 \%)$ in combination and $10 \%$ FBS is beneficial for the recovery medium, allowing a greater number of morphologically viable oocytes and $\mathrm{BCB}$ assay. At the IVM stage, only the addition of $0.4 \%$ BSA would not be of interest as a supplement in IVM medium for bovine oocytes. Thus, FBS (both 5 and $10 \%$ levels) and BSA $(0.8 \%)$ can be used alone or in combination with a similar positive effect on oocyte maturation.

\section{Declarations}

\section{Acknowledgments}

We thank the people at the slaughterhouse and industrial refrigerator of Mossoro (Brazil) for supplying the biologic material. 


\section{Funding}

This research was supported by grants from the Conselho Nacional de Desenvolvimento Científico e Tecnológico (CNPq, Brazil, grant number 477710/2013-1) and Coordenação de Aperfeiçoamento de Pessoal de Nível Superior (CAPES, Finance Code 001). Alexsandra $\mathrm{F}$ Pereira is a $\mathrm{CNPq}$ researcher (Process no.306963/2017-5).

\section{Conflicts of interest}

The authors declare they have no conflicts of interest with regard to the work presented in this report.

\section{Author contribution}

PH Fernandes-França designed the study, acquired and analyzed the data, and drafted the paper. MV Oliveira-Santos, GP OliveiraLira, and A Azevedo-Borges contributed with the experiments. A Fernandes-Pereira designed and guided the experimental work, analyzed the data, drafted and revised the paper.

\section{References}

AliA, SirardMA. Effect of the absence orpresence of various protein supplements on further development of bovine oocytes during in vitro maturation. Biol Reprod 2002; 66(4):901-905. DOI: https://doi.org/10.1095/biolreprod66.4.901

Ambrogi M, Dall'Acqua PC, Rocha-Frigoni NAS, Leão BCS, Mingoti GZ. Transporting bovine oocytes in a medium supplemented with different macromolecules and antioxidants: Effects on nuclear and cytoplasmic maturation and embryonic development in vitro. Reprod Domest Anim 2017; 52(3):409-421. DOI: https://doi.org/10.1111/rda.12923

Araújo MS, Midyan DG, Volpato R, Landim FC. Principais mecanismos envolvidos na maturação oocitária em bovinos: da oogenese a maturação in vitro. Encic Biosf 2014; 10:2373-2388. DOI: http://hdl.handle.net/11449/137126
Ashry M, Lee K, Mondal M, Data TK, Folger JK, Rajput SK, Zhang K, Hemeida NA, Smith GW. Expression of TGF $\beta$ superfamily components and other markers of oocyte quality in oocytes selected by brilliant cresyl blue staining: relevance to early embryonic development. Mol Reprod Dev 2015; 82(3):251-264. DOI: https://doi.org/10.1002/mrd.22468

Boruszewska D, Sinderewicz E, KowalczykZieba J, Grycmacher K. Studies on lysophosphatidic acid action during in vitro preimplantation embryo development. Domest Anim Endocrinol 2016; 54:15-29. DOI: https://doi.org/10.1016/j.domaniend.2015.08.003

Carrocera S, Caamaño JN, Trigal B, Martín D, Díez C. Developmental kinetics of in vitro-produced bovine embryos: an aid for making decisions. Theriogenology 2016; 85(5):822-827. DOI: https://doi.org/10.1016/j. theriogenology.2015.10.028

Chasombat J, Nagai T, Parnpai R, Vongpralub T. Pretreatment of in vitro matured bovine oocytes with docetaxel before vitrification: effects on cytoskeleton integrity and developmental ability after warming. Cryobiology 2015; 71(2):216-223. DOI: https://doi.org/10.1016/j. cryobiol.2015.07.002

Chen H, Zhang L, Zou P, Wang Y. Effects of oocyte vitrification on epigenetic status in early bovine embryos. Theriogenology 2016; 86(3):868-878. DOI: https://doi.org/10.1016/j. theriogenology.2016.03.008

Crocomo LF, Marques Filho WC, LandimAlvarenga FC, Bicudo SD. Aspectos bioquímicos e ultraestruturais da maturação oocitária. Vet Zoot 2011; 18:542-552. DOI: http://hdl.handle.net/11449/141245

Del Collado M, Saraiva NZ, Lopes FL, Cruz MH, Gaspar RC, Oliveira CS, Perecin F, Garcia JM. Efeitos da redução ou substituição do soro fetal bovino por outros compostos na maturação in vitro de oócitos bovinos. Pesqui Vet Bras 2014; 34(7):689-694. DOI: http://dx.doi.org/10.1590/ $\underline{\mathrm{S} 0100-736 \times 2014000700014}$ 
Del Collado M, Saraiva NZ, Lopes FL, Gaspar RG, Padilha LC, Costa RR, Rossi GF, Vantini R, Garcia JM. Influence of bovine serum albumin and fetal bovine serum supplementation during in vitro maturation on lipid and mitochondrial behaviour in oocytes and lipid accumulation in bovine embryos. Reprod Fertil Dev 2015; 28:1-12. DOI: https://doi.org/10.1071/RD15067

Dinopoulou V, Drakakis P, Kefala S, Kiapekou E, Bletsa R, Anagnostou E, Kallianidis K, Loutradis D. Effect of recombinant-LH and hCG in the absence of FSH on in vitro maturation (IVM) fertilization and early embryonic development of mouse germinal vesicle $(\mathrm{GV})$-stage oocytes. Reprod Biol 2016; 16(2):138-146. DOI: https://doi.org/10.1016/j.repbio.2016.01.004

Galeati G, Vallorani C, Bucci D, Bernadini C, Tamanini C, Parmeggiani A, Spinaci M. Daidzein does affect progesterone secretion by pig cumulus cells but it does not impair oocytes IVM. Theriogenology 2010; 74(3):451-457. DOI: https://doi.org/10.1016/j. theriogenology.2010.02.028

Gonçalves PB, Barreta MH, Sandri LR, Ferreira $\mathrm{R}$, Antoniazzi AQ. In vitro production of bovine embryos: the state of the art. Rev Bras Reprod Anim 2007; 31:212-217. DOI: https://doi. org/10.1079/PAVSNNR201510048

Leivas FG, Brum DS, Fialho SS, Saliba WP, Alvim MTT, Bernardi ML, Rubin MIB, Silva CAM. Fetal calf serum enhances in vitro production of Bos taurus indicus embryos. Theriogenology 2011; 75(3):429-433. DOI: https://doi.org/10.1016/j.theriogenology.2010.08.017

Maia RC, Mogolllón EM, Dubeibe DF, Pena B, Dias AJB. Effect of seasonality on the quality of bovine oocytes selected by brilliant cresyl blue method. Rev Colomb Cienc Pecu 2017; 30:259-266. DOI: https://doi.org/10.17533/udea.rccp.v30n4a01

Muñoz AI, Mischler S. Electrochemical quartz crystal microbalance and X-Ray Photoelectron spectroscopy study of cathodic reactions in bovine serum albumin containing solutions on a physical vapour deposition-CoCrMo biomedical alloy. Electrochim Acta 2015; 180:96-103. DOI: https://doi.org/10.1016/j.electacta.2015.08.017

Pereira MM, Costa FQ, Oliveira AP, Serapião RV, Machado MA, Viana JHM, Camargo LSA. Quantificação de transcritos maternos em oócitos bovinos submetidos a diferentes condições de maturação. Arq Bras Med Vet Zootec 2010; 62(6):1394-1400. DOI: http://dx.doi.org/10.1590/S0102-09352010000600015

Santos MVO, Borges AA, Queiroz Neta LB, Pereira AF. Influence of the recovery method on the quanti-qualitative parameters of bovine oocytes. ARS Vet 2016; 32:105-109. DOI: https://doi.org/2175-0106

Santos MVO, Queiroz Neta LB, Borges AA, Pereira AF. Influence of commercially available follicle stimulating hormone on the in vitro maturation of bovine oocytes. Semin Cienc Agrar 2017; 38(3):1393-1402. DOI: http://dx.doi. org/10.5433/1679-0359.2017v38n3p1393

Sugimura S, Yamanouchi T, Palmerini MG, Hashiyada Y, Imai K, Gilchrist RB. Effect of pre-in vitro maturation with cAMP modulators on the acquisition of oocyte developmental competence in cattle. J Reprod Dev 2018; 64(3):233-241. DOI: https://doi.org/10.1262/ jrd.2018-009

Ulloa SMB, Heinzmann J, Herrmann D, Timmermann B, Baulain U, Grobfeld R, Diederich M, Lucas-Hahn A, Niemann H. Effects of different oocyte retrieval and in vitro maturation systemson bovine embryo development and quality. Zygote 2014; 23(3):367-377. DOI: https://doi.org/10.1017/ $\underline{\mathrm{S} 0967199413000658}$

Van Der Valk J, Brunner D, Desmet K, Fex svenningsen A, Honegger $\mathrm{P}$, Knudsen LE, Lindl T, Noraberg J, Price A, Scarino ML, Gstraunthaler G. Optimization of chemically defined cell culture media-replacing fetal bovine serum in mammalian in vitro methods. Toxicol In Vitro 2010; 24(4):1053-1063. DOI: https:// doi.org/10.1016/j.tiv.2010.03.016 
Varago FC, Mendonça LF, Lagares MA. Bovine in vitro embryo production: state of art and perspective of a constant evolution technique. Rev Bras Reprod Anim 2008; 32:100-109. DOI: https://doi.org/10.1079/201510048 